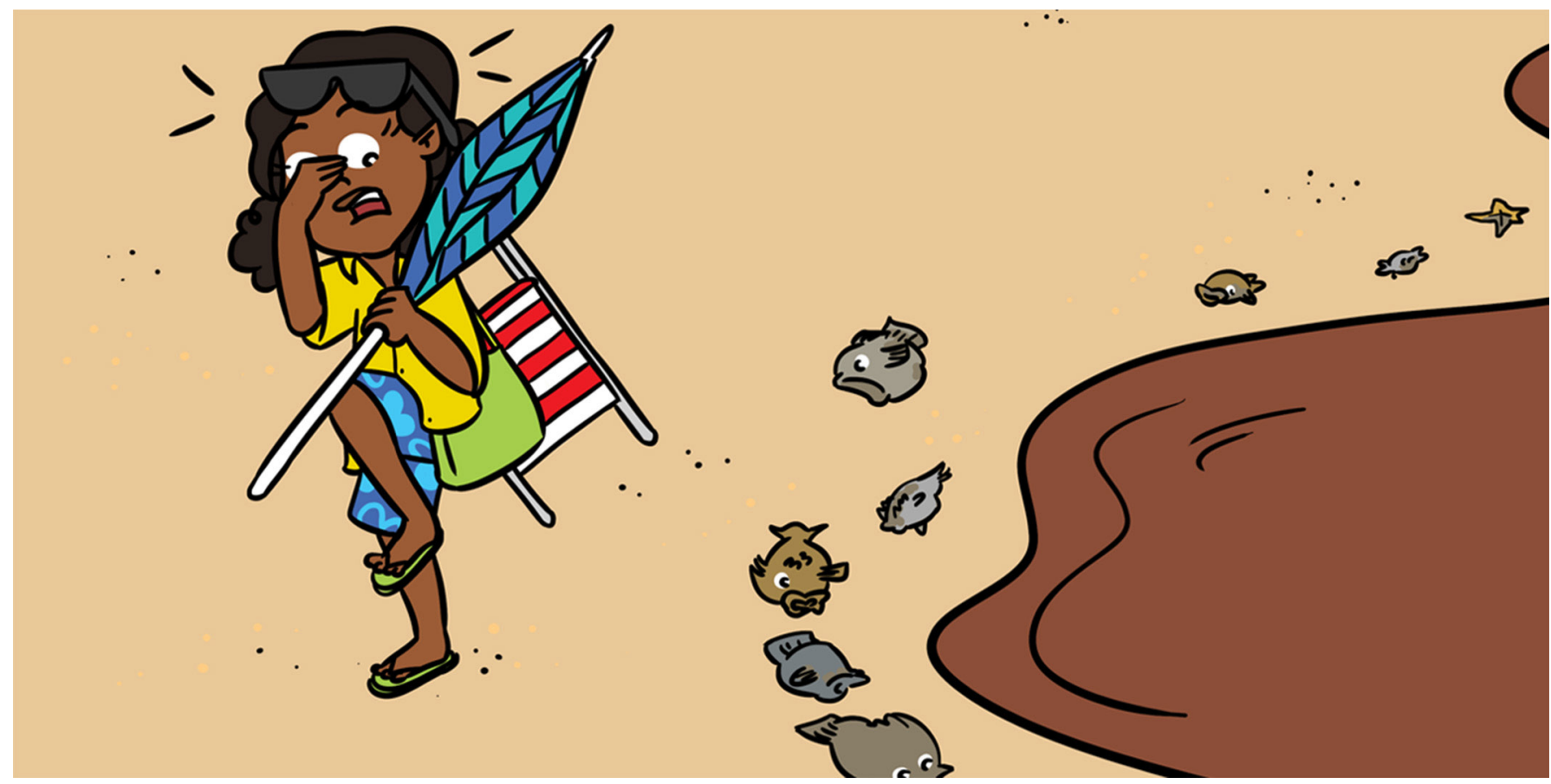

\title{
WHY WERE THE WATER AND BEACHES IN WEST FLORIDA SO GROSS IN SUMMER 2018? RED TIDES!
}

\section{Patricia M. Glibert*}

Horn Point Laboratory, University of Maryland Center for Environmental Science, Cambridge, MD, United States

\section{YOUNG REVIEWER:}

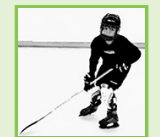

SEBASTIAN

AGE: 9
The coast of Florida experienced a red tide during summer 2018, an event that turned the sea reddish-brown and caused tons of fish and hundreds of turtles and manatees to die. People also got sick from breathing the sea air. The red tide was caused by the overgrowth of tinybut toxic-algae, microscopic organisms called Karenia brevis. Florida has red tides every year, but this was the largest event in more than 10 years. It is thought that recent hurricanes and wet weather resulted in nutrients, mostly from fertilizer used on land, to be washed into the sea, causing pollution that fed the rapid growth of these unwanted algae. Once the bloom started, there was not much that could be done to stop its growth. We can, however, take actions to reduce nutrient pollution. There is much work to be done to make our waters clean and safe.

\section{WHAT IS A RED TIDE?}

Those of you who live in Florida, or whose families planned a trip to western Florida during this past summer (2018), likely saw lots of dead 


\section{RED TIDE}

A harmful algal bloom that causes the water to turn a reddish color, due to the accumulation of algae that have a reddish pigment.

\section{HARMFUL ALGAL}

\section{BLOOM}

Growth of algae that may cause fish kills or seafood contamination through toxins, or that may alter ecosystems in negative ways, or may cause human health problems through toxins that may be carried by the air.

\section{Figure 1}

(A) Dead fish that washed ashore in Sanibel, Florida in August 2018. (B) This was caused by a red tide that colored the water a reddish brown. (C) The red tide is a result of accumulations of the toxic

dinoflagellate species Karenia brevis, as seen under a microscope.

(A) is reproduced from Joe Raedle (used with permission of Getty Images), (B) is from Rick Bartleson (with permission), and (C) from the Florida Fish and Wildlife Research Institute (creative commons license). fish on the beach (Figure 1A). The water was gross, a reddish brown color, and maybe you or your family members could not stop coughing if you did walk on the beach. It may have spoiled your vacation. This was the result of red tide. What was it and why was it so bad this summer?

Red tide is an event that happens when lots of algae grow in the water. Not just any algae, but a particularly poisonous type of algae. Algae are microscopic plants that live in the water. Every drop of water normally contains hundreds of thousands of these tiny, tiny plants. Algae are natural and important, as they are the vegetables for the food web of the sea. There are many thousands of different types of algae. Algae use sunlight and $\mathrm{CO}_{2}$ to grow and they, in turn, feed the fish, crabs, oysters, and other organisms. But, some species of algae can be harmful or toxic. Just like some plants on land, such as poison ivy, certain algae can make chemicals that harm both fish and people. When algae increase substantially in number, we say that they bloom (like flowers), and the harmful ones create a harmful algal bloom [1]. Some call this

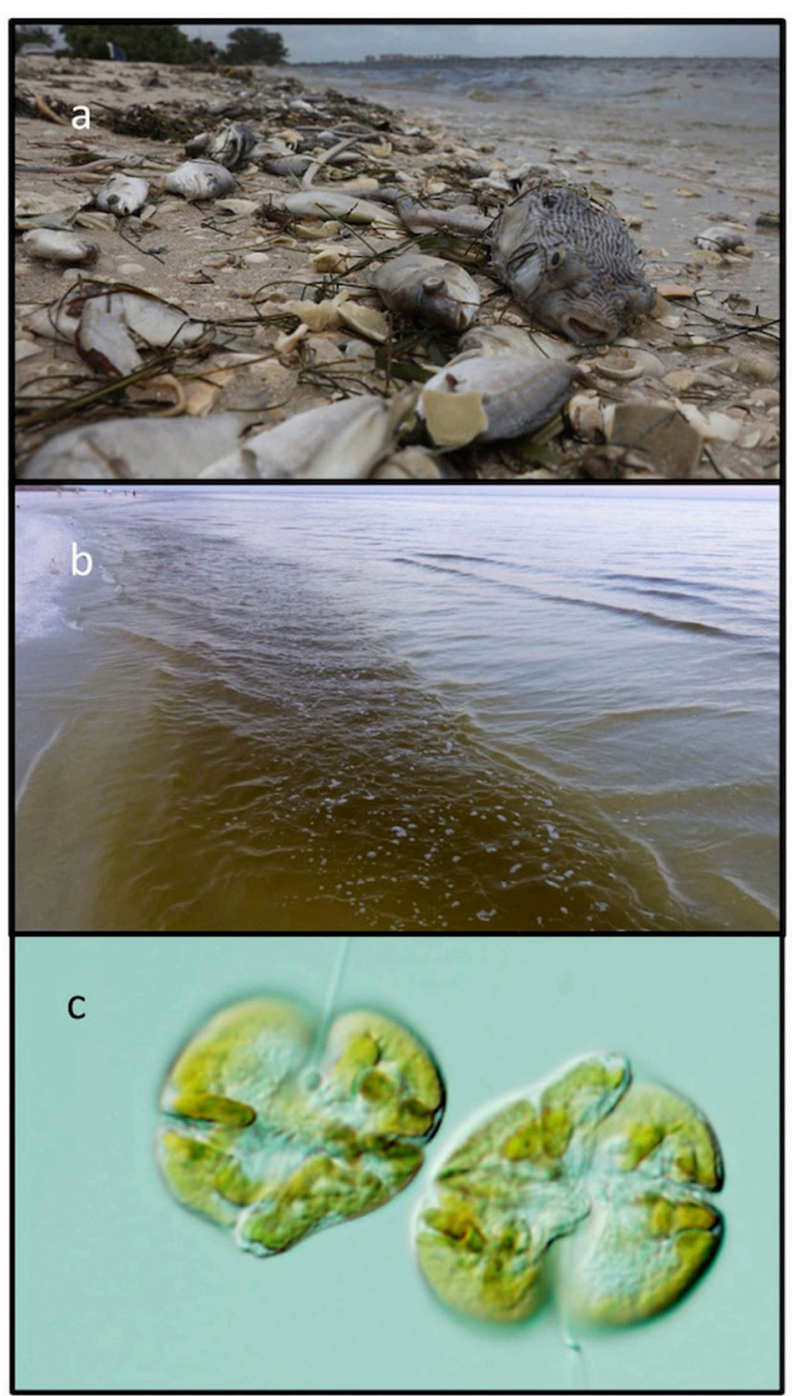

Figure 1 


\section{DINOFLAGELLATE}

A class of algae, many of which make harmful algal blooms and/or are toxic.

\section{EUTROPHICATION}

Unnatural increase of nutrients in a body of water. The results can be harmful algal blooms, fish kills, or other effects that negatively impact the ecosystem. type of bloom a red tide, because the algae may be reddish in color, so in large enough numbers they color the sea red (Figure 1B). The most common red tide organism of Florida is named Karenia brevis (Figure 1C). It is a type of algae called dinoflagellates.

\section{WHY DO RED TIDES OCCUR AND WHY WAS THIS SO BAD DURING THE SUMMER OF 2018?}

Karenia brevis are naturally found in the Gulf of Mexico. They have been around since at least the Spanish explorers noticed the red tides, in the sixteenth century [2]. These tiny cells normally grow when waters get warm in spring and early summer, but they may stay offshore in the deeper Gulf of Mexico waters. Just like land plants, algae also need nutrients, nitrogen and phosphorus, to grow and reproduce. Nutrients are the liquid food or natural fertilizers in the water.

There are natural sources of nutrients in the sea, but nutrient pollution can occur when nutrients from the land run off into local waters. Nutrient pollution can be thought of as the rocket fuel that can make algae grow rapidly. It gives them a buffet of nutritious substances to live on [3]. The term for the enrichment of waters with excess nutrients, leading to algal blooms and the problems they cause, is eutrophication. There are many sources of nutrients that make their way from the land to the sea. We apply lots of nutrients (fertilizers) on land to make lawns and golf courses look green. The biggest source of nutrients comes from agriculture, and Florida has lots of farmland. Most nutrients used in agriculture stay on land and support the growth of crops. But some can run into rivers and streams when it rains, and can also seep into ground water. Even more nutrients run off into rivers and streams when it rains hard (Figure 2). Nutrients also make their way into waterways when we flush the toilet. Without enough nutrients, red tide blooms do not occur and this is what happens most summers. Karenia brevis cells may start to grow, but they die out because there are not a lot of natural nutrients in the Gulf of Mexico.

During the summer of 2018, we think that there were many more nutrients supporting the growth of Karenia brevis. Many scientists think that this bloom actually began in September of 2017, after Hurricane Irma hit Florida. This was a powerful storm, with drenching rains and winds high enough to knock over trees and cause power outages. With all this water washing nutrients from the land, the algae had plenty of nutrients and they started to grow during the fall and winter of 2017. As summer came, the bloom grew even larger. More rains came, as the summer of 2018 was very wet, so the nutrients kept coming too. This was also the case in 2005-2006, when a large red tide followed other hurricanes (Katrina, Rita, Wilma). 


\section{Figure 2}

The progression of events that are thought to lead to red tides. Nutrients (fertilizer) from land can get washed into streams, lakes, rivers, and the sea following rain events, and these nutrients provide the fuel to make the red tide algae grow. Once the algae grow in number, its toxins kill fish and can also get carried in sea spray, making people sick. Warnings are issued to beachgoers and shellfishing areas may be closed if the algal cell number is too high The middle panel (3) is from the University of Maryland Center for Environmental Science Integration and Application Network.

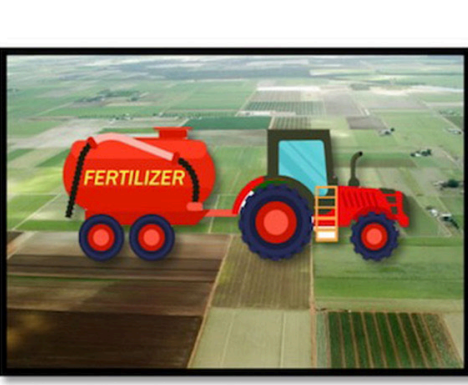

1-Fertilizer (sometimes in excess of agricultural needs) is applied to fields

$$
\text { lakes and eventually the sea }
$$$$
\text { fields }
$$

2- Rains (made worse by hurricanes) wash some of this fertilizer into streams,

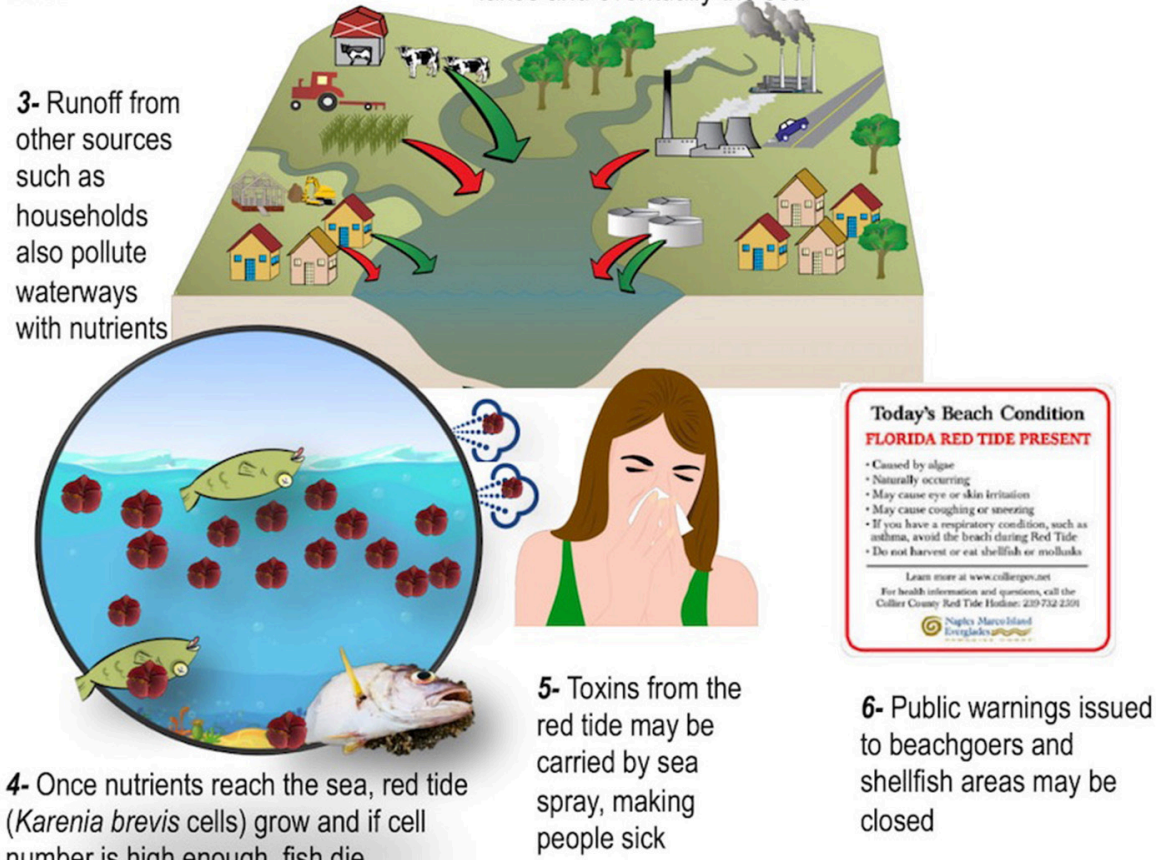

\section{WHY WERE THERE DEAD FISH ON THE BEACH AND WHY WAS EVERYONE COUGHING?}

As many as 100 manatees, a 26-foot juvenile shark, 300 turtles (including endangered species) and at least 100 tons of fish died due to this red tide [4]. When these dead animals washed up on beaches, it was smelly and in some places, it was so bad that people said their lungs were burning. Many people started coughing as soon as they came near the beach. Some people had to be taken to the hospital. It was Karenia brevis that killed the fish and made people sick.

Karenia brevis makes fish and people sick from its toxin (poison), called brevetoxin. The toxin is tasteless and odorless. When fish come in contact with this toxin, they die. When people come in contact with Karenia brevis or its toxins, they cough. People can be exposed to this poison 


\section{FILTER FEEDERS}

A group of animals, such as shellfish, that eats by straining food particles from the water without selecting individual food particles.

\section{NEUROTOXIN SHELLFISH POISONING (NSP)}

A human health problem resulting from eating shellfish contaminated with the algal toxin called brevetoxin that comes from the harmful algal bloom species Karenia brevis. The main symptoms are nausea, diarrhea and headaches.

Figure 3

An example of a weekly map of the distribution of the algae that cause red tides, and the number of algal cells found per liter of seawater, in Florida. In this map, the red and orange dots show where the algal cells created the largest problems for beachgoers and for fish. because the algal cells break open in the waves and release the toxin, which is carried in the sea spray that people breathe in when they walk on the beach.

People can also get very sick from these algal blooms when they eat shellfish, like oysters, that have eaten the algae. Oysters are called filter feeders, because they get their food by filtering tiny algae from the water. Oysters suck in the water, taking whatever type of algae is present, good or bad. Shellfish do not get sick or die from poisonous algae, but people who eat oysters that have filtered these algae do get sick. The toxin affects the nervous system. Oysters do not have a nervous system, so they do not get sick. People who eat oysters with these toxins may throw up or have diarrhea. Fortunately, they get better in a few days. This disease is known as neurotoxin shellfish poisoning, or NSP [5]. People can get sick from oysters when there are about 5,000 Karenia brevis cells in each liter of seawater. To protect people from getting sick, the Florida government does not allow oystermen to collect or sell oysters when there are 5,000 or more Karenia brevis cells per liter of water. The red tide of summer 2018 was so bad that there were places with 200 times more Karenia brevis than this (Figure 3)! The governor had to declare a state of emergency!

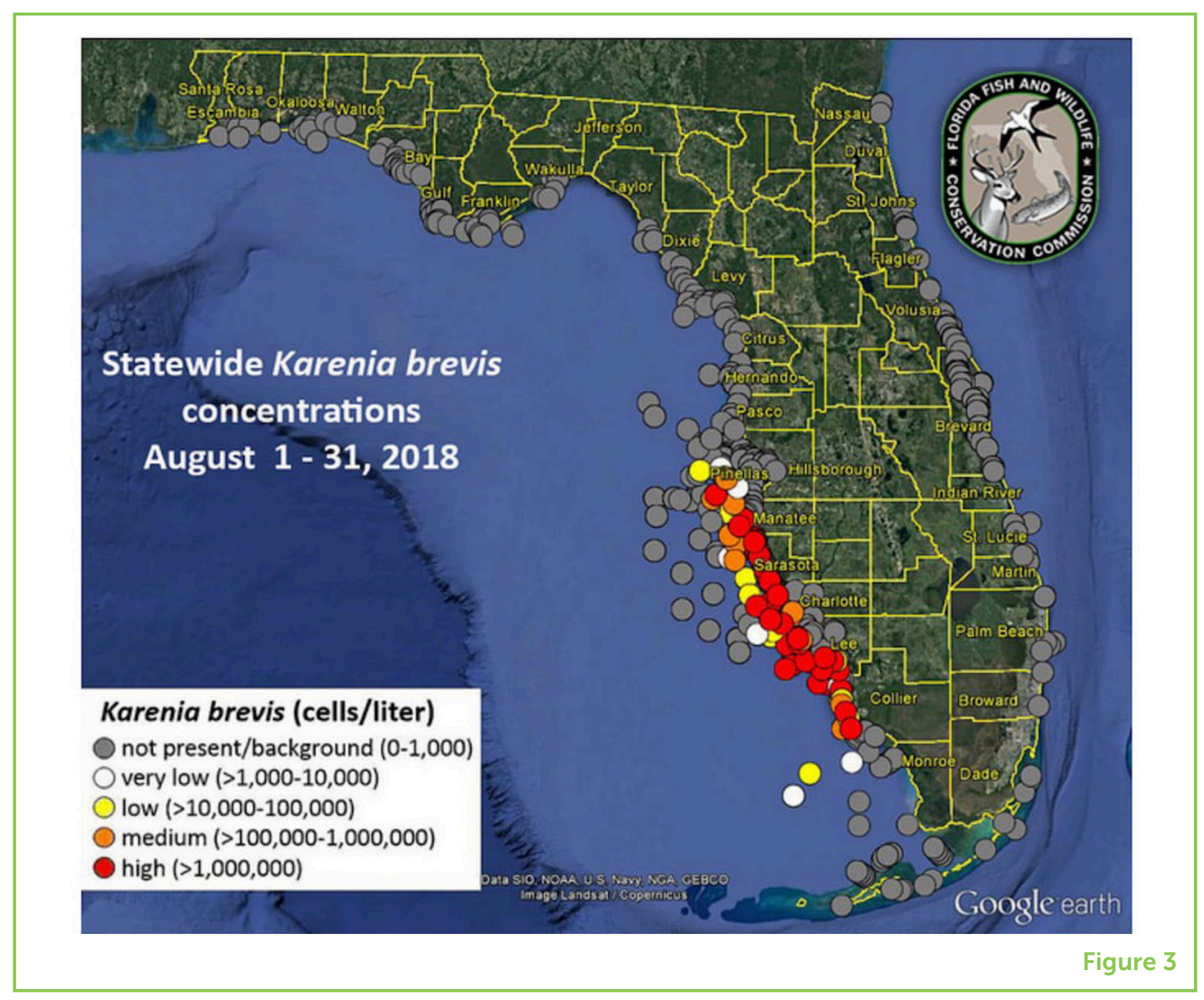



HAPPEN?

There are many harmful algae bloom species found throughout the world, each with a different type of toxin. Due to eutrophication, harmful algal blooms are increasing in frequency, size, duration, and in the human health and ecological problems that they cause. Some harmful algae live only in the water, while others live in the sediment or attached to other surfaces in the water, for some or all of their life cycle. There are also harmful algae that live in freshwater, and many of these are very toxic too. In early summer, Florida experienced a freshwater harmful bloom in the eastern part of the state, turning parts of Lake Okeechobee and the coastal lagoons into a gooey, slimy green mess. Both the eastern Florida bloom and the western red tide are likely related to nutrient pollution and the wet weather that caused nutrients from land to escape into the lake and the sea.

\section{WHAT IS BEING DONE TO STOP HARMFUL ALGAL BLOOMS?}

Scientists and politicians are debating what can be done to stop harmful algal blooms. There is no easy way to stop a bloom once it has started. Clearly, we cannot stop hurricanes or rainy weather. What we can do is reduce nutrient pollution. This will take political action to enforce laws, but there is also much we can do ourselves. We should not over-fertilize our lawns. We can talk to our local officials to make sure they take all the actions they can to reduce nutrient pollution. Also, if you are at the beach and you see stranded animals, such as manatees, dolphin or turtles, call the authorities. Pay attention to local warnings about beach closures and seafood closures! Although the science of understanding how and why harmful algal blooms occur has been rapidly advancing, the chances of reducing these events or their impacts are, unfortunately, not very good. When climate change and rising temperatures are also considered, the outlook is even worse. The growth of many of the algal species that form these blooms increases in warmer conditions. There is much work to be done to make our waters clean and safe. Our waters need your help!

\section{For More Information on Red Tides and Harmful Algae}

https://oceanservice.noaa.gov/facts/redtide.html https://myfwc.com/redtidestatus https://www.whoi.edu/redtide/ 


\section{ACKNOWLEDGMENTS}

This work was supported by an award from the National Oceanic and Atmospheric Administration (number NA17NOS4780180). The author wishes to thank Todd Kana, Emily Rogowski and Amy Glibert for helpful comments on the manuscript. This paper is contribution number 5529 from the University of Maryland Center for Environmental Science and 924 from the NOAA ECOHAB Program.

\section{REFERENCES}

1. Glibert, P. M., Anderson, D. M., Gentien, P., Granéli, E., and Sellner, K. G. 2005. The global, complex phenomena of harmful algal blooms. Oceanogr. 18:136-47. doi: 10.5670/oceanog.2005.49

2. Steidinger, K. A. 2009. Historical perspective on Karenia brevis red tide research in the Gulf of Mexico. Harmful Algae 8:549-61. doi: 10.1016/j.hal.2008.11.009

3. Heisler, J., Glibert, P. M., Burkholder, J. M., Anderson, D. M., Cochlan, W., Dennsion, W. C., et al. 2008. Eutrophication and harmful algal blooms: a scientific consensus. Harmful Algae 8:3-13. doi: 10.1016/j.hal.2008.08.006

4. Wei Haas, M. 2018. Red Tide is Devastating Florida's Sea Life. Are Humans to Blame? National Geographic. Available online at: https://www.nationalgeographic.com/ environment/2018/08/news-longest-red-tide-wildlife-deaths-marine-life-toxins/

5. Backer, L. C., and McGillicuddy, D. J. 2006. Harmful algal blooms at the interface between coastal oceanography and human health. Oceanogr. 19:94-106. doi: 10.5670/oceanog.2006.72

SUBMITTED: 10 October 2018; ACCEPTED: 16 January 2019; PUBLISHED ONLINE: 04 February 2019

EDITED BY: Francisco Barona-Gomez, Centro de Investigación y de Estudios Avanzados del Instituto Politécnico Nacional, Mexico

CITATION: Glibert PM (2019) Why Were the Water and Beaches in West Florida so Gross in Summer 2018? Red Tides! Front. Young Minds 7:10. doi: 10.3389/frym.2019.00010

CONFLICT OF INTEREST STATEMENT: The author declares that the research was conducted in the absence of any commercial or financial relationships that could be construed as a potential conflict of interest.

COPYRIGHT @ 2019 Glibert. This is an open-access article distributed under the terms of the Creative Commons Attribution License (CC BY). The use, distribution or reproduction in other forums is permitted, provided the original author(s) and the copyright owner(s) are credited and that the original publication in this journal is cited, in accordance with accepted academic practice. No use, distribution or reproduction is permitted which does not comply with these terms. 


\section{YOUNG REVIEWER}

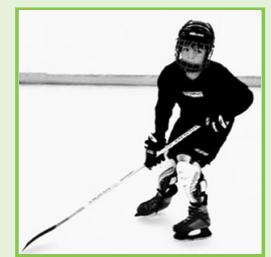

\section{SEBASTIAN, AGE: 9}

I like playing ice hockey, soccer, tennis, baseball, and reading. I really like animals. I like to camp, ski, play in the snow, swim, climb trees, playing and riding my bike.

\section{AUTHOR}

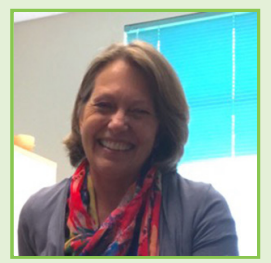

\section{PATRICIA M. GLIBERT}

I study algae because I hope what we are doing makes a difference. These are certainly interesting times to be an ecologist studying water quality. Harmful algal blooms are increasingly everywhere, and nutrient pollution and eutrophication are increasing. It used to be difficult to explain what I studied to my non-scientists friends and relatives; now, they read the headlines of water quality issues and algal blooms frequently. I study algae all around the world, from Chesapeake Bay to Florida, from Europe to China! *glibert@umces.edu 